\title{
Effect of Long Term Administration of Synthetic Thyrotropin-Releasing Hormone (TRH) on Pituitary-Thyroid Function in Rats
}

\section{Hidetaro MORI}

The Second Department of Internal Medicine, Kobe University School of Medicine, Kobe, Japan

A number of recent neuroendocrinological studies have revealed that the releasing factor (RF) plays an essential role in the regulation of pituitary tropic hormone secretion. Folkers and his collegue have synthesized a preparation called pyro-glutamyl-histidylproline amide which has distinct TRH activity both in vivo and in vitro. The effect on the pituitary-thyroid function in rats receiving long term administration (from 7-35 days) using 10 or $100 \mu \mathrm{g} / 100 \mathrm{~g}$ B.W. of TRH synthesized after Gillessen et al. was observed.

The following results were obtained:

(1) The TRH-treated rats showed no changes in weight, food and water intake compared with saline treated rats.

(2) Pituitary-function in rats receiving long term administration of TRH: Resting levels of TSH in the TRH-treated rats were slightly elevated. Pituitary weight and pituitary TSH contents were decreased in rats treated with synthetic TRH for 15-22 days $(\mathrm{p}<0.005)$.

In rats treated with long termsynthetic TRH, 50 and $100 \mathrm{ng}$ of $\mathrm{TRH}$ induced prominent increases of plasma TSH at 10-30 minutes, and plasma TSH levels at 60 minutes were higher than at 0 minute. These findings indicate that plasma TSH response to 50 and $100 \mathrm{ng}$ of TRH in TRH-treated rats was delayed and sustained.

Studies were performed on the pituitary responsiveness to $\mathrm{TRH}$ in $\mathrm{T}_{4}$ pretreated rats. In rats pretreated with $3 \mu \mathrm{g}$ of $\mathrm{T}_{4}, 50$ and $25 \mathrm{ng}$ of $\mathrm{TRH}$ showed no increase of plasma TSH at 10 minutes. These results show that $\mathrm{T}_{4}$ induced more prominent inhibition on TRH action in rats treated with TRH than in saline treated rats.

(See pp. $1067 \sim 1076$ ) 


\section{合成 Thyrotropin Releasing Hormone (TRH) 連続投与の下垂体 TSH 分泌動態に及ぼす 効果にかんする実験的研究}

神戸大学医学部第 2 内科（主任：馬場 茂明教授）

森頴 太 郎

（昭和48年 9 月 2 日受付）

Gillessen らの方法で合成した TRH (pyro-glutamyl-histidyl-proline amide) を $10 \mu \mathrm{g}$ 及び $100 \mu \mathrm{g} /$ $100 \mathrm{~g}$, 体重を毎日 1 回ラットに最低 7 日から最高35日間連続腹腔内投与し, 間脳下垂体系におよぼす影 響を観察するてとにより TRH 連続投与の効果についての基礎的検討を試みた。この合成 TRH 連続 投与群は対照とした生食水連続投与群に比して, 血漿 TSH resting level のやや上昇傾向を認め, 下 垂体重量及び下垂体内 TSH 量の減少，少量の合成 TRH 亿対する血漿 TSH の反応時間の遅延，か つ，持続性の傾向， thyroxine による TRH 作用の易抑制性などが観察された。

\section{I 。緒言}

1947年 Green，Harris $\left.{ }^{1}\right)$ が中枢神経系による下垂体前葉分泌の調節機序として視床下部起源の液性因子 を想定し，その後，Saffran，Schally ら²)は，乙の液性因子をReleasing Factor（RF）と名づけた。下垂 体 TSH 分泌の調節に働く液性因子は，TRF (Thyrotropin Releasing Factor) と呼ばれその抽出分離への 努力が続けられてきた。1969年までの数年間にわたる諸家の研究3445) は，TRF が glutamine, histidine, proline の 3 つのアミノ酸よりなる tripeptide である事を証明し，1969年 8 月， Folkers ${ }^{6}$ ， Guillemin ${ }^{7)}$ らに よつて合成された tripeptide, すなわち, pyro-glutamyl-histidyl-proline amide (pyro-Glu-His-Pro $\mathrm{NH}_{2}$ )) に強力な TRF 作用のある事が判明した8).

以来, 乙の合成 TRF の生物作用にかんする研究9) 16) は種々報告されてきたが，合成 TRH 連続投与に よる下垂体 TSH 分泌動態に及ぼす影響についての報告は未だない.

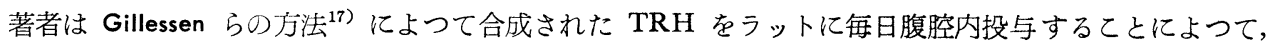
間脳下垂体系に及ぼす影響を観察するてとにより TRH 連続投与の効果についての基礎的検討を試みいく つかの知見を得たので報告する。

\section{II．実験方法並びに実験対象}

\section{1. 実 験 動 物}

体重 110 120g の Swiss-Webster 系雄ラット及び体重 10１1g の D.D. 系雌マウスをオリエンタル固 型飼料 MF にて, 温度, 湿度, 光, 音などを出来るだけ一定条件下で飼育したものを使用した。

\section{TRF 連続投与法}

ラットに合成 TRH あるいは, 対照として生食水を毎日 1 回腹腔内投与し, 最終投与 24 時間後に, ペン トバルビタール麻酔下 $(4.5 \mathrm{mg} / 100 \mathrm{~g}$. 体重) 亿頸静脈上り合成 TRH を投与し, その後, 10，30，60分後 と経時的に他側頚静脈より採血した。 また, TRH 投与 4 時間前に $\mathrm{T}_{4}$ 処置し, 合成 TRH を頸静脈投与 
し，投与前，投与後 $10 ， 30 ， 60$ 分に採血し，遠沈後血漿を分離し直ちに凍結保存し TSH 検定に供した，又， 合成 TRH あるいは，生食水を長期連続腹腔内投与したラットを無麻醉下に，断頭屠豰し，下垂体後葉を 取り除いた後, 下垂体前葉を取り出し，3匹一群とし生理食塩水にて homogenize し, 遠沈後の上清を稀釈 して TSH 検定に供した.

又, 上述した方法で取り出した下垂体前葉の重量を直ちに torsion balance を用い湿潤重量を測定し対照 群と比較した.

\section{TSH 検定法}

TRH の検定は Mckenzie 変法 ${ }^{18}$ そよつた。すすなわち, D.D. 系雌マウス（体重14〜16g）に Na ${ }^{131} \mathrm{I} 10 \mu \mathrm{Ci}$ を腹腔内注射し， 4 及び24時間後に，L-thyroxine-Na $10 \mu \mathrm{g}$ を皮下投与し， ${ }^{131} \mathrm{I}$ 投与72時間に実験に供した. この前処置したマウスを軽いエーテル 林醉下に, 眼静脈叢より $0.1 \mathrm{ml}$ 採血し, 又, その後, 尾静脈より $\mathrm{TRH}$ 連続投与法の項で得られた検体を $0.4 \mathrm{ml}$ 静注し, 静注 2 時間後, 再び軽いエーテル麻醉下に, 反対 側眼静脈叢より $0.1 \mathrm{ml}$ 採血し, 各々の blood radioactivity を well-type-scintillation counter で測定し, 検体投与後の blood radioactivity を, 検体投与前の blood radioactivity に対する百分率で示した。最低測

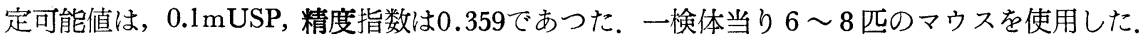

\section{4. 合成 TRH 標品の検定}

著者らの使用した TRH は Gillessen ら ${ }^{17)}$ の方法に準じて合成されたもので， pyroglutamyl-histidylproline amide の酢酸塩である。乙の標品の生物作用並びに特異性にかんする検討結果は, 既に一部報告 ${ }^{13)}$ 14)したが，その単回投与の効果を以下の点について改めて検討した.

i ) 合成 TRH 単回投与による血中 TSH の変動

ラットをペントバルビタールで麻酔し頸静脈内に合成 TRH 100ng/ $100 \mathrm{~g}$. 体重投与し，前， 5，15，30， 60分後に，他側頸静脈より採血し，TSH 検定に供した。血漿 TSH の変動を血中 ${ }^{131}$ I radioactivity より

Fig. 1. Time course of plasma TSH response after single injection of synthetic TRH (100ng/100g B.W.) in rats

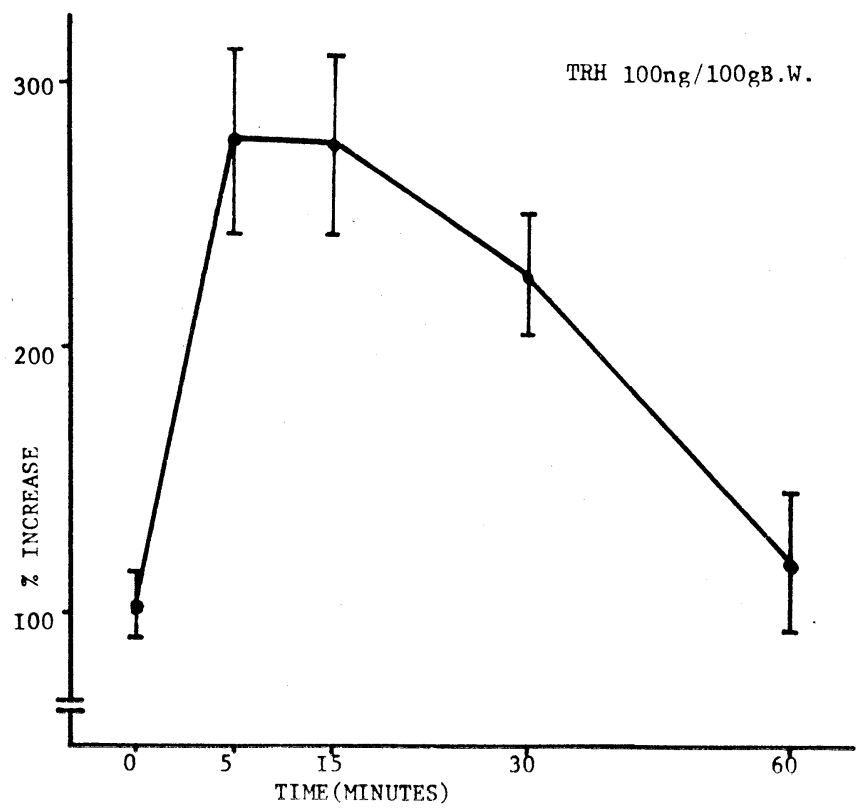


みると，血漿 TSH は， 5 分ですでに頂值に達し，15分においても5 分とほぼ同じレベルにあり，以後漸次 下降した (Fig. 1).

ii) 合成 TRH の用量反応相関

ラットに $100 \mathrm{~g}$ 体重あたり合成 TRH 1, 5, 10 $\mu$ g 投与すると, 夫々の群で投与10分後の血漿 TSH 活性 は上昇した。 この TSH 上昇は, 生食水投与群に比べ何れも推計学上有意の上昇を示した。 また, Table 1 に示すでとく投与量と TSH 上昇との間に用量反応関係が成立した。

iii） TRH 作用に対する Thyroxine の抑制作用.

予め 4 時間前に, ラットに $\mathrm{T}_{4}$ の $1,5,10 \mu \mathrm{g}$ を皮下投与した後，合成 $\mathrm{TRH}$ を単回頸静脈内投与した. 結果は Table 2 亿示すように，ての合成 TRH 300ng 投与は， $5 \mu \mathrm{g}$ 以上の $\mathrm{T}_{4}$ により TRH 作用の抑制 を受けた。すすなわち， $\mathrm{T}_{4}$ は合成 TRH の作用を抑制するが，乙の抑制効果には，予め投与する $\mathrm{T}_{4}$ 量と合 成 TRH の投与量との間に容量依存的結果がみられた。

iv）乙の他，Saffran ${ }^{19)}$ 亿準じ検定した in vitro のラット下垂体短時間 incubation においても，合成 TRH の TSH 放出効果が存在する事をみた ${ }^{14)}$. 更に, との合成 TRH に牛 TSH, ラット TSH を賦活化 しない事, 並びに, TSH 样作用のない事を確認した。

Table 1. Effect of synthetic TRH on plasma TSH of rat

\begin{tabular}{|c|c|c|}
\hline Treatment & Blood radioactivity $(\% \text { of initial })^{*}$ & $\mathrm{p}$ \\
\hline Saline & $67.0 \pm 8.2$ & - \\
\hline Synth. TRH $1.0 \mu \mathrm{g}$ & $206.0 \pm 16.7$ & $<0.005$ \\
\hline Synth. TRH $5.0 \mu \mathrm{g}$ & $230.2 \pm 22.8$ & $<0.005$ \\
\hline Synth. TRH $10.0 \mu \mathrm{g}$ & $324.0 \pm 17.1$ & $<0.005$ \\
\hline
\end{tabular}

$*$ mean \pm S.E.

Table 2. $\mathrm{TRH}$ induced $\mathrm{TSH}$ response in $\mathrm{T}_{4} *$ pretreated rats

\begin{tabular}{r|c|r}
\hline \multicolumn{1}{c|}{ Treatment } & Blood radioactivity $(\%$ of initial)** & P \\
\hline No T 4 +Synth. TRH $0.3 \mu \mathrm{g}$ & $301.7 \pm 12.4$ & - \\
$1.0 \mu \mathrm{g} \mathrm{T}_{4}+$ Synth. TRH $0.3 \mu \mathrm{g}$ & $301.6 \pm 41.6$ & N.S . \\
$5.0 \mu \mathrm{g} \mathrm{T}_{4}+$ Synth. TRH $0.3 \mu \mathrm{g}$ & $211.2 \pm 18.6$ & $<0.025$ \\
$10.0 \mu \mathrm{g} \mathrm{T}_{4}+$ Synth. TRH $0.3 \mu \mathrm{g}$ & $119.0 \pm 6.9$ & $<0.005$ \\
\hline
\end{tabular}

* Rats were pretreated with $\mathrm{T}_{4} 4 \mathrm{hrs}$. before experiment.

** mean \pm S.E.

上述のような作用特性をもつ合成 TRH を使用して，ラットに長期投与を行なつた。

\section{5. 実験成績の推計学的処理}

In vivo, in vitro で放出された TSH の倹定には，一群6〜8匹のマウスを使用した。処置ラット群の 群間差の有意差検定は Student “ $t$ ” test によつた。

\section{III. 実 験 成 績}

1. 合成 TRH 連続投与によるラットの体重, 水及び食物袪取量の変動

合成 $\mathrm{TRH} 100 \mu \mathrm{g} / 100 \mathrm{~g}$ 体重あるいは， $10 \mu \mathrm{g} / 100 \mathrm{~g}$ 体重を 34 日間毎日腹腔内連続投与し，各ラットについ て毎日一定時間に体重測定した所, 生食水連続投与対照群に比較して有意の差は得られなかつた。また，1 
Fig. 2. Changes of body weight, food and water intake in the rats received long term administration of synthetic TRH (10 or $100 \mu \mathrm{g} / 100 \mathrm{~g}$ B.W.)
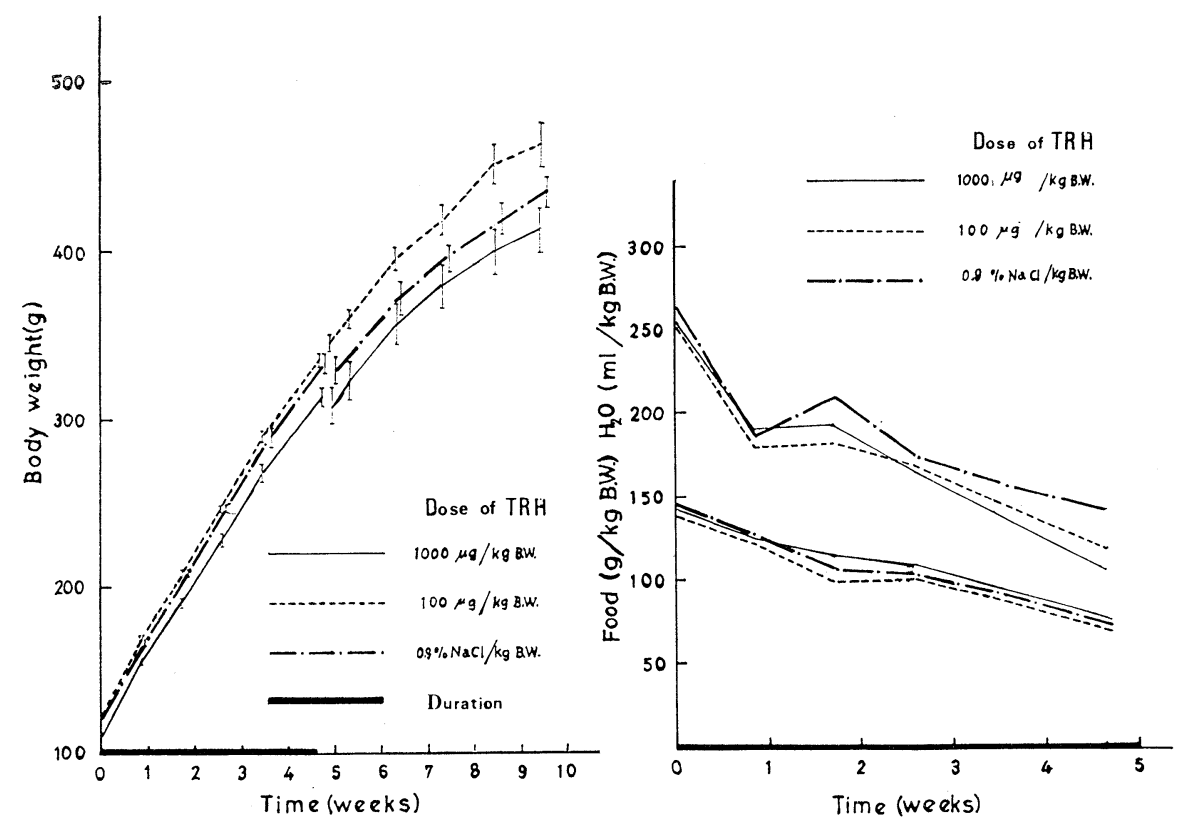

Fig. 3. Changes of plasma TSH level $24 \mathrm{hrs}$. after final injection of long term administration of synthetic TRH $(100 \mu \mathrm{g} / 100 \mathrm{~g}$ B.W. $)$ in rats

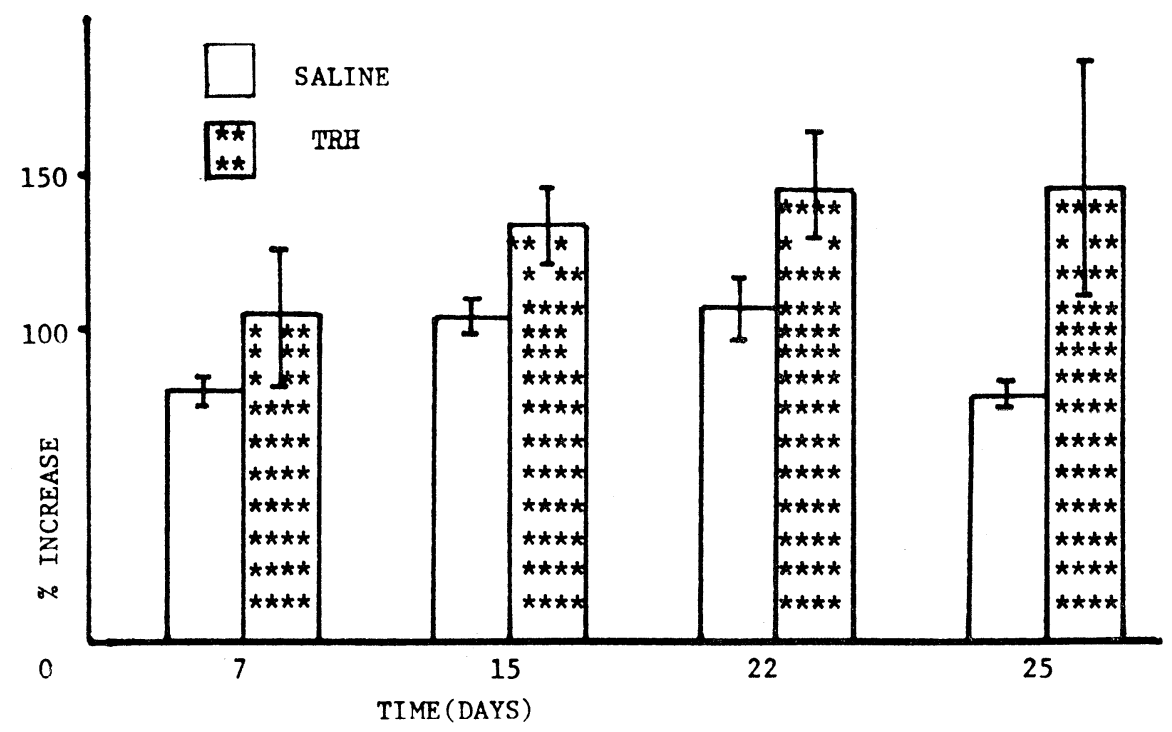


日の水，食物摄取量を毎日計測して比較したが，乙れもまた有意の差は得られなかつた。

すなわち, 合成 TRH 連続投与はラットの体重, 水及び食物摄取量に対して影響を及ぼさないといえる (Fig. 2).

2. 合成 TRH 連続投与後の血獎 TSH Level の変動

一定の条件下で飼育したラットに, 一定期間毎日 1 回合成 TRH $100 \mu \mathrm{g} / 100 \mathrm{~g}$, 体重を, 対照として生食水 $0.2 \mathrm{ml} / 100 \mathrm{~g}$. 体重腹腔内注射し, 最終投与 24 時間後に, ペントバルビタール麻酔下に 頸静脈より採血して TSH 活性を測定した. 血漿 TSH の resting level は, 対照群と比較して TRH 連続投与群の方がやや高 い傾向にあつたが有意ではなかった。特に，連続投与日数 $15 ， 22 ， 25$ 日のラットにおいては，対照群に比し， 血中 TSH 高値を示したが，乙れも推計学上有意でなかつた。また投与日数による差も明らかでなかつた (Fig. 3).

\section{3. 合成 TRH 連続投与後の下垂体重量, 下垂体内 TSH 量}

15 日間毎日合成 TRH $100 \mu \mathrm{g} / 100 \mathrm{~g}$. 体重を腹腔内投与したラット (17頭, 平均体重 $245 \pm 6.6 \mathrm{~g}$ ), 及び毎 日生食水 $0.2 \mathrm{ml} / 100 \mathrm{~g}$ 体重, を投与したラット（12頭, 平均体重 $239 \pm 5.6 \mathrm{~g} ）$ の下垂体前葉の重量を測定し た. $\mathrm{TRH}$ 連続投与群では, 平均下垂体重量 $6.5 \pm 0.3 \mathrm{mg}$, 体重 $100 \mathrm{~g}$ 当りでは, $2.6 \pm 0.1 \mathrm{mg}$ であり, 生 食水連続投与群では, 下垂体重量 $7.0 \pm 0.3 \mathrm{mg}$, 体重 $100 \mathrm{~g}$ 当りでは $2.9 \pm 0.1 \mathrm{mg}$ であつた。すなおち, 合成 TRH 連続大量投与によつて下垂体重量の減少が $\mathrm{P}<0.05$ の有意差をもつて証明された.

また，下垂体内 TSH 含量を測定した所，15日間連続合成 TRH 投与群の亚均下垂体重量は，体重 $100 \mathrm{~g}$, 当り $2.6 \pm 0 \mathrm{mg}$ で, $\mathrm{mg}$ 当りの TSH 含量は, $4.2 \pm 0.7 \mathrm{mUSP}$, 生食連続投与群の下垂体重量は, $100 \mathrm{~g}$ 当り $2.9 \pm 0.1 \mathrm{mg}$ で, $\mathrm{mg}$ 当りの TSH 含量は, $17.3 \pm 0.1 \mathrm{mUSP}$ で両群間には有意の差が認められた。すすなわ ち，合成 TRH 連続投与により下垂体 TSH 含量も減少する事を示した (Table 3).

Table 3. Changes of pituitary weights and TSH contents after long term administration of synthetic TRH in rats

\begin{tabular}{|c|c|c|c|c|c|c|}
\hline \multirow{2}{*}{ Treatment } & \multirow{2}{*}{$\begin{array}{c}\text { No. of } \\
\text { rats }\end{array}$} & \multirow{2}{*}{$\begin{array}{l}\text { Pituitary weight } \\
\text { mg/100g B.W. }\end{array}$} & \multirow{2}{*}{$\mathrm{P}$} & \multicolumn{2}{|c|}{ Pituitary TSH contents } & \multirow{2}{*}{$\mathrm{P}$} \\
\hline & & & & $\begin{array}{l}\text { Blood radioactivity } \\
(\% \text { of initial) }\end{array}$ & mU.S.P./mg & \\
\hline Saline for 15 days & 17 & $2.9 \pm 0.1$ & - & $231.3 \pm 20.3$ & $17.3 \pm 0.1$ & - \\
\hline TRH* for 15 days & 12 & $2.6 \pm 0.1$ & 0.05 & $102.3 \pm 18.2$ & $4.2 \pm 0.7$ & $<0.005$ \\
\hline
\end{tabular}

* Synthetic TRH $100 \mu \mathrm{g} / 100 \mathrm{~g}$ B.W.

** mean \pm S.E.

\section{4. 合成 TRH 長期投与ラットにおける TRH-TSH 反応}

合成 TRH あるいは生食水 22 日間連続投与したラットに, TRH 最終投与 24 時間に合成 TRH 25 ある いは, $100 \mathrm{ng} / 100 \mathrm{~g}$, 体重を頸静脈より投与し, 投与前, 投与後 $10,30,60$ 分に反対側頸静脈より採血し, 直 ちに血漿分離し凍結した後 TSH 検定に供した。血漿 TSH の変動をみた所，生食水連続投与群では，10 分で頂值に達し，60分で前値に復するに反して，TRH 連続投与群では，頂値は10分と30分の間にあり，か つ，60分でもなお前値に比し高い值をとつた，從つて TRH 連続投与群は, 少量の合成 TRH に対して遅 延反応を示し，かつ持続した TRH の増量を示す傾问を認めた.

\section{5. 合成 TRH 長期投与ラットにおける TRH 効果に対する $T_{4}$ の影響}

TRH の效果は thyroxine によつて抑制される事が明らかとなつたが，合成 TRH 長期投与ラットにお ける $\mathrm{T}_{4}$ の TRH 作用抑制を観察する目的で, TRH 22 日間連続投与ラットに，予め $\mathrm{T}_{4} 3 \mu \mathrm{g} / 100 \mathrm{~g}$ 体重を 実験 4 時間前に皮下投与し，TRH 効果について検討した。 すなわち，ペントバルビタールで麻酔したラッ トに合成 TRH 50, 25, 5ng/100g, 体重, 頸静脈より投与し, 投与前及び投与後10分の血漿 TSH の変動を 
Fig. 4. Plasma TSH response on definite dose of synthetic TRH in the rats received long term administration of synthetic TRH $(100 \mu \mathrm{g} / 100 \mathrm{~g}$ B.W.)
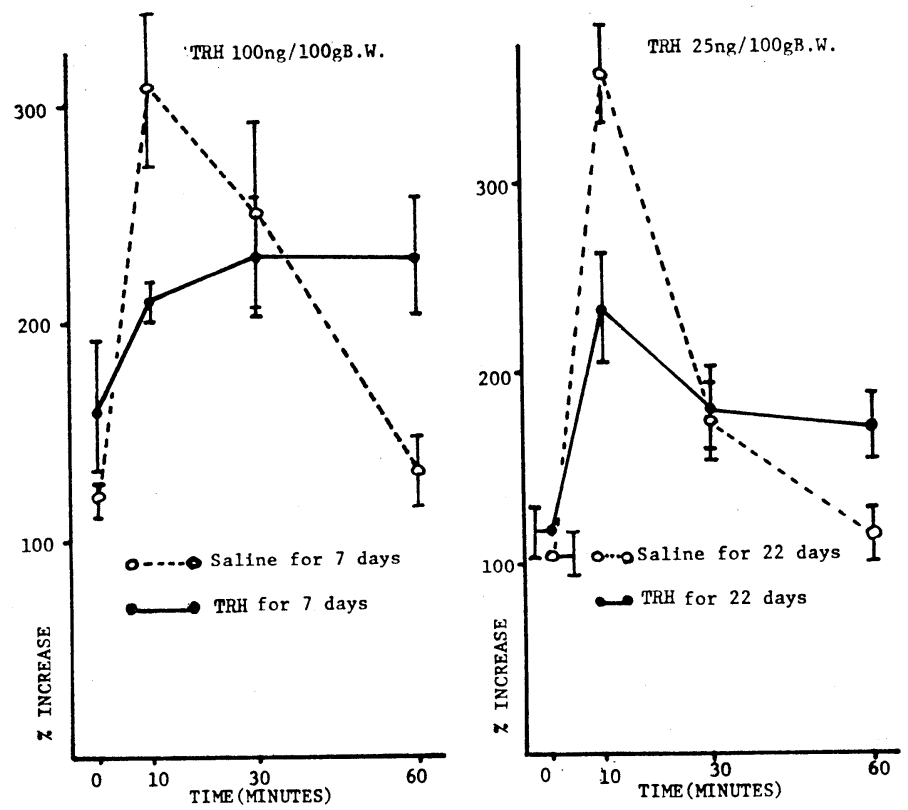

Fig. 5. Effects of $\mathrm{T}_{4}$ on the response to various dose of synthetic $\mathrm{TRH}$ in the rats received long term administration of synthetic TRH $(100 \mu \mathrm{g} / 100 \mathrm{gB} . \mathrm{W}$.

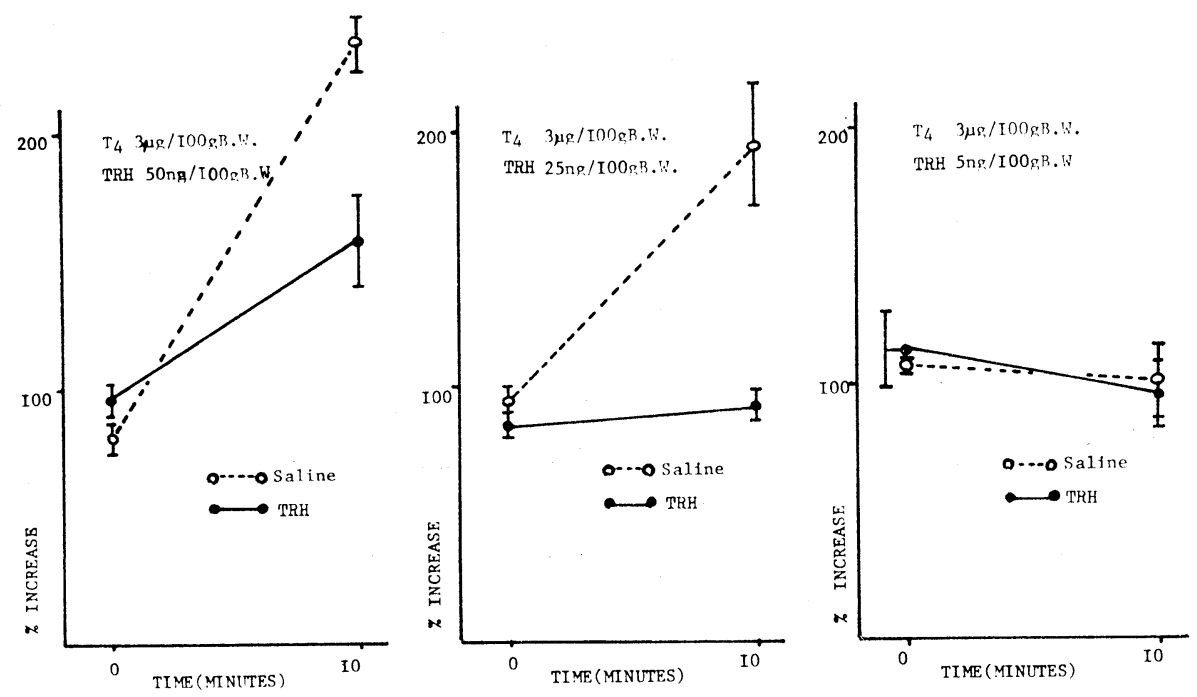


みると，図に示すでとく (Fig. 5), TRH 50ng 投与では, TSH の増量は, 生食水群 $235.0 \pm 12.1 \%, T R H$ 連続投与群 $158.3 \pm 18.2 \%(\mathrm{P}<0.05)$, また， TRH $25 \mathrm{ng}$ 投与では，生食水群 $192.8 \pm 27.0 \%, \mathrm{TRH}$ 連 続投与群 $91.0 \pm 6.6 \%(\mathrm{P}<0.05)$ で有意差を認めた。すなわち，TRH 連続投与群は，生食水連続投与群 に比べて $\mathrm{T}_{4}$ の抑制を受けやすいととが判明した。 なお，TRH 5ng 投与では，両群共に TRH 作用が $\mathrm{T}_{4}$ により抑制された.

\section{IV. 考按}

\section{1. 合成 TRF について}

著者が使用した TRH 標品は，既に報告したように ${ }^{13) 14)}$, pyro-Glu-His-Pro $\left(\mathrm{NH}_{2}\right)$ の構造をもち，in vivo, in vitro における基礎的検討の結果から TSH 放出作用をもち，かつ，その作用が特異的なものであ るととは明らかである，著者が使用した TRH の投与量は，従来の報告6)15)16)31)に比べきいが，てれは比 較的大量の $\mathrm{TRH}$ を連続投与した場合の内分泌代謝面への影響を知ろうとする著者の意図に基づくもので ある. このような投与量，投与形式によつて，血漿 TSH level，下垂体重量，下垂体内 TSH 量，血漿 $\mathrm{TSH}$ の $\mathrm{TRH}$ に対する反応性, $\mathrm{T}_{4}$ と $\mathrm{TRH}$ 作用の関連性, ラットの体重, 水及び食物摂取量の変動につ いて観察し, 間脳下垂体, 甲状腺系に及ぼす TRH 効果の解明を意図した。

2. 合成 TRH 連続投与による下垂体機能への影響

i ) 血漿 TSH の resting level

TSH 分泌に日内変動を認めるという報告 ${ }^{20)}$ を別として, 下垂体 TSH 分泌の調節機構については, 視床 下部由来の TRH による促進と末梢血中甲状腺ホルモンによる抑制とによつて，主として調節されている と考えられている。著者の実験において, 連続 TRH 投与したラットの安静時血漿 TSH は, 対照群と比 較して高い傾向にあるが有意の上昇ではない，ての安静時 TSH レベルの軽度上昇の機序は必ずしも明らか ではない. TRH 単回投与の場合，血漿 TSH の増加は，5１0分を頂值として60分でもとに復する事が著 者及びその他の研究者 ${ }^{9}{ }^{10}{ }^{11121)}$ によつも報告されている，従つて，著者の実験では最終投与24時間後に採 血しているので，連日投与の効果を，単に 1 回投与の繰返しと見なせば，24時間後の TRH 効果は少いと 考えられる. しかしながら，連日投与を単なる 1 回投与の繰返しと見なさず，連日投与に個有な効果一たと えば蓄積効果を想定するならば血中 Resting TSH レベバの軽度の上昇を理解することが可能となる。しか し，乙の点について断定しうるには至らず，かつ現在他からの同様の検討報告も見られない. 今後，さらに TRH 投与量, 投与期間を変えて観察を加え結論に達するべきであろうと思われる.

ii) 下垂体内重量と下垂体内 TSH 量

Andersen $^{22)}$ は, ラットの生殖腺切除術を行ない，下垂体重量の増加をみると報告し，また，Andersen ${ }^{23)}$ 及び Baylon ${ }^{24)}$ は, estrus 期には，下垂体重量の増加， diestrus 期には，下垂体重量の減少があると報告し ている。，一方，加令による下垂体重量の相対的減少については，Andersen ${ }^{23)}$ ，Hatani ${ }^{25)}$ が報告している.

著者は，ラットに大量の合成 TRH を毎日投与することによつて下垂体重量の減少する事をみた. Sinha ${ }^{26)}$ ， Meites $^{27)}$ ，田中 ${ }^{28)}$ らは，TRH が，TSH 放出のみならず，TRH 生合成にも働きかける可能性を報告して いる. 一方, Redding ${ }^{29)}$ や Bowers ${ }^{30)}$ は, TRH 効果を下垂体内 TSH 量の減少率で推定することを試みた が，乙の事からも理解されるように，TRH 投与は結果として下垂体 TSH 量を減少させる可能性が示唆さ れる. 著者は，ラットに大量の TRH を毎日投与するととにより下垂体重量の減少のほか下垂体内 TSH 量の著名な減少をも観察した。

Bowers $^{30)}$ は，少量の porcine TRH をマウスに単回投与すると投与 2 時間後の TSH 含量は減少してい るが，大量投与では TSH 含量に変化がないと報告している。 Redding ${ }^{29)}$ は，マウスに純化 TRH を単回 投与し， 5 分後に断頭屠穀し下垂体前葉の TSH 含量を測定し，TRH 4ng は顕著な TSH 含量の減少を 起ししたが，2〜4時間後には投与前の含有量に復元したと報告している.

ことには, TRH の作用が単に TSH 放出のみに㗢くか, あるいは, TSH 生合成にも㗢くかの問題が存 
在し，かつ，単回投与と連続投与の投与形式による差が存在するものと考光られる．著者の連続投与実験で は，下垂体内 TSH 量は有意の減少を示したので，TRH がTSH 生合成に働くとしても TSH 放出が生 合成を上廻つたものと理解出来る。

Bowers $^{31}$ は, ラットにおいて下垂体移殖術を行ない, その後, 合成 TRH $3 \mu \mathrm{g}$ 連続腹腔内投与して, 下 垂体での TSH 合成は, TSH 放出に遅れるという事を報告している. 田中 ${ }^{28}$ は, 下垂体の TSH 分泌能に 及ぼす添加物質の影響に関する研究で, TRH 添加は早期に TSH 放出を促進し, その後, 下垂体内の TSH が增量すると報告している。すなわち，TSH 合成は放出に遅れて始まるというととである。伊藤ら ${ }^{322}$ は, ラットを寒冷暴露する事により下垂体内 TSH が減少するてとをみている。 てのように，外因性ないしは， 内因性 TRH に対し比較的早い時期には TSH 放出が著明であり, 次の phase で TSH 生合成が行なわ れる可能性が指摘されるが, 何れにしても, 著者の大量 TRH 連続投与の条件では, 下垂体内 TSH 量は 著明減少する事は明らかである。

iii） TRH 連続投与ラットにおける合成 TRH 投与に対する血漿 TSH の変動

Bowers $^{33)}$ は, 高純化 porcine TRH をクレチン症例に単回投与し, bioassay, radioimmunoassay にて血 漿 TSH の変動をみた。すなわち, porcine TRH $300 \mu$ g 投与により 3 〜 分で頂値に達し，45分まで徐々 に下降し120分で前值に復した。

佐古田ら ${ }^{34)}$ によと, ラットに bovine TRH (Fraction D) $100 \mu \mathrm{g}$ 単回投与した場合の血漿 TSH の 変動は，6分で頂値に達し，以後漸次下降するという。同様の事を，Bowers ${ }^{9}$ ， Hershmann ${ }^{11)}$, Fleisher ${ }^{10) ，}$ Hall ${ }^{12)}$ ，大槻 ${ }^{35)}$ らが合成 TRH を用いて報告しているが，著者の使用した合成 TRH においても，Fig. 1. 亿 示す如く, ラットに合成 TRH 100ng 単回投与により血漿 TSH は, 5 分ですでに頂值を示し, 以後漸次 下降し60分で前值に復した。乙の様に，TRH-TSH 反応には時間的に反応相関がある。然るに，TRH 連 続投与中のラットに任意の 1 日を選んで少量の TRH 投与した場合には, 血漿 TSH の頂値は10分と30分 の間にあり，かつ，60分でもなお高い值をとつた。 すなわち，少量の合成 TRH に対して遅延，かつ，持 続した TSH 增量反応を呈する傾向がるあといえる. 大槻 ${ }^{35)}$ は, 下垂体障害症例, 甲状腺機能低下症, 原発 性甲状腺機能低下症において少数例であるが，TRH に対する TSH 反応の頂值が遅れ，かつ，60分でもな お高值が続く，いわば，遅延反応ともいうべきTSH 分泌形式が存在するといつている．更に，原発性甲 状腺機能低下症では, TRH 投与前に, 既に, TSH の resting level の高值を指摘している.すなわち, 頂值到達時間が遅れ, かつ, 前値復元時間が遅れるという点で, 七ト原発性甲状腺機能低下症と TRH 連 続投与ラットの反応パタンとは類似している。しかし， resting level の TSH 值に扑て，両者は明らか 飞異つており，TRH 連続投与ラットは，投与前値 TSH が低い。乙のような TRH 連続投与ラットで, 頂值到達時間が遅れる機序については, 前述のように, TRH 連続投与ラットの下垂体 TSH 量が少い事実 に関連する可能性か推測される。一般に，内分泌腺組織内のホルモン含有量が少い条件下では，そのホルモ ン分泌刺激に対するホルモン放出反応が遅れる事実が従来より指摘されてきたが，ててにも同様の機序が存 在するものと考える.

iv) $\mathrm{TRH}$ 効果住対する $\mathrm{T}_{4}$ の影響

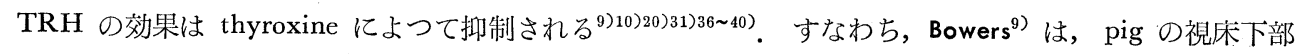
より抽出した純化 TRH $2.7 \mu \mathrm{g}$ をラットに投与した時，予め， 2 時間前に $\mathrm{T}_{4} 0.9 \mu \mathrm{g}$ を投与するととによつ て TRH 効果は一部抑制され， $\mathrm{T}_{4} 2.7 \mu \mathrm{g}$ で完全に抑制されたと報告している. Vale ${ }^{36)}$ は, 抽出 TRH $8 \mathrm{U}$ 投与の時， $\mathrm{T}_{4} 2.5 \mu \mathrm{g}$ で完全にその作用を抑制する，また， $\mathrm{T}_{4} 10 \mu \mathrm{g}$ の時は，TRH $22.95 \mathrm{U}$ まで抑制する が，53.37Uでは $\mathrm{T}_{4}$ による抑制は認められないと報告し，下垂体レベルでの $\mathrm{TRH}$ と $\mathrm{T}_{4}$ との間の dose dependent な negative interaction のあるてとを指摘している. Bowers ${ }^{31)}$ らは，マウスで $\mathrm{T}_{3} 25 \mathrm{ng}$ 投与 は合成 TRH 18ng の作用を抑制すると報告している。 また，佐古田 ${ }^{41)}$ ，福田 ${ }^{42}$ は，ラットにおいて牛純化 $\mathrm{TRH}$ (Fraction D) $50 \mu \mathrm{g}$ 投与では， $\mathrm{T}_{4} 3 \mu \mathrm{g}$ により下垂体からの TSH 分泌が抑制されるが，100 $\mu \mathrm{g}$ 投与 では， $\mathrm{T}_{4} 5 \mu \mathrm{g}$ 以上により抑制されたと報告している。 また，佐古田 ${ }^{13)}$ は，合成 TRH $1 \mu \mathrm{g}$ 投与は， $\mathrm{T}_{4}$ 
$3 \mu \mathrm{g}$ により抑制を愛け, TRH $10 \mu \mathrm{g}$ 投与では $\mathrm{T}_{4} 3 \mu \mathrm{g}$ で TSH 分泌は抑制されず $\mathrm{T}_{4} 10 \mu \mathrm{g}$ で初めて抑制 されたと報告している，著者が今回の実験を始めるにあたつて，合成 $\mathrm{TRH}$ と $\mathrm{T}_{4}$ の相関を調べた所, 300 $\mathrm{ng} の \mathrm{TRH}$ は $\mathrm{T}_{4} 5 \mu \mathrm{g}$ 以上で抑制されるという結果が得られた。 さて，てのように一定の $\mathrm{T}_{4}$ 前処置では 完全に一定量の TRH の TSH 放出作用が抑制されるが，逆にTRH 投与量を次第に増加すると，一定量 の $\mathrm{T}_{4}$ による抑制効果を突破して TSH 放出を起す.

すなわち，乙とに， $\mathrm{T}_{4}$ の variable set point ともいうべき下垂体レベルでの $\mathrm{T}_{4}$ と TRH の negative interaction があり，それが TSH 分泌を決定するといえる。

さて，著者は合成 $\mathrm{TRH}$ 大量連続投与ラットにおける $\mathrm{T}_{4}$-TRH の関連性を調べるため, 連続投与ラッ トに 4 時間前に $\mathrm{T}_{4} 3 \mu \mathrm{g}$ 皮下注し, 合成 TRH $50,25,5 \mathrm{ng}$ 投与した所, $50,25 \mathrm{ng}$ 投与では, 生食水連続 投与群と比較して $\mathrm{T}_{4}$ の抑制を受け易いという結果がでた。 また，5ng 投与では両群共に TRH 作用が抑 制されていた。 このととは, 外因性 TRH の増加のため, 下垂体が最大限の TSH 放出刺激を受けている ので，更に外因的に投与した TRH には反応しにくく，そのため，生食水投与群に比べて， $\mathrm{T}_{4}$ により抑制 され易いのか，あるいは，下垂体内 TSH 量减少のためか，興味ある事実である，今後，更に検討を要する 問題であると考えられる.

$\mathrm{T}_{4}$ と TRH の関係を福田 ${ }^{43}$ は, 甲状腺剔除ラットにおいてみている. すなわち, 甲剔群では, TRH 効 果は認められず, 甲剔後, $\mathrm{T}_{4} 5 \mu \mathrm{g}$ 及び $10 \mu \mathrm{g}$ を 3 日間投与した群, すなわち, 血中甲状腺ホルモンレベル が正常よりもやや高いと考光られる群では，TRH 効果は良好である. 更に大量の $\mathrm{T}_{4}$ を投与した群（甲剔 $+\mathrm{T}_{4} 5 \mu \mathrm{g}$ あるいは $10 \mu \mathrm{g} 7$ 日間連続投与）では, 再び, TRH 効果は抑制され, TRH の効果は血中甲状 腺ホルモンレベルと微妙な関係にあると報告している。著者の TRH 連続投与ラットでは, 最終注射後 24 時間では血清 PBI がやや高い傾向にあるが的, 連続投与ラットにおける内因性甲状腺ホルモンの下垂体一 の影響は必ずしも明らかでない，TRH の作用は，血中甲状腺ホルモンレベルだけでなく，先に述べたよう に下垂体内 TSH 含有量によつて修飾されると思われる，すなわち将来，TRH か治潦応用された場合，内 因性甲状腺ホルモン増量による TRH 作用抑制を除くためには, 至適な TRH の投与量, 投与間隔を設定 するてとが治療目的を達するために必要である事を示している.

\section{V. 結論}

合成 TRH をラットに最短 7 日, 最長 34 日間連続投与し, 主として下垂体一甲特腺系機能に及ぼす影響 を検討し，以下の結果を得た。

1) ラットの体重及び水分摄取には影響を及ぼさなかつた。

2) 血漿 TSH の resting level の上昇傾向が認められたが, 推計学的には有意でなかつた。

3) 下垂体重量, 下垂体内 TSH 量の減少を認めた。

4) 連続投与ラットで TRH 最終注射後 24 時間に投与された合成 TRH そ対して, 血漿 TSH の反応時 間の遅延並びに持続する傾向が認められた。

5) 予め投与された thyroxine により，TRH 作用は抑制され易く，血中 $\mathrm{T}_{4}$ 濃度，TRH，下垂体内 TSH 量との間に相互関係があるととを想定した。

稿を終るにあたり, 御指導, 御校閲を晹わつた馬場茂明教授に深甚なる謝意を表します。。また，直接の御 助言, 御教示を頂いた佐古田雅弘講師に厚く御礼申しあげます。また, 御協力いただいた研究室の諸兄に感 謝致します。 TRH の合成，その他に関して多大の御協力をいただいた大五栄養渡辺博士に感謝致すます。 なお，本論文の要旨は，第44回日本内分泌学会総会（昭和46年 4 月，東京）において発表した。

\section{文献}

1) Green, J.D. and G.W. Harris : J. Endocr. $5: 136$ (1947).

2) Saffran, M., A.V. Schally and B.G. Benfey : Endocrinology, $57: 439$ (1955).

3) Schally, A.V., T.W. Redding, C.Y. Bowers, 
and J.F. Barrett : J. Biol. Chem. 244 : 4077 (1969).

4) Burgus, R., Stillwell, R.N. McGkloskey, J.A., Ward, D.N., Sakiz, E., and R. Guillemin : The physiologit, 9 : 149 (1966).

5) Tsuji, S., M. Sakoda, and M. Asami : In "Integrative mechanism of neuroendocrine system" (Itoh, S. ed.) Hokkaido Univ. Med. Lib. Ser. pp. 63,Sapporo (1968). 6) B $\phi$ ler, J., F. Enzmann, K. Folkers, G.Y. Bowers and A,V. Schally : Biochem. Biophys. Res. Comm. 37 : 705 (1969).

7) Burgus, R., Dunn, T.F., Desiderio, D., and Guillemin, R. : C.R. Acad. Sci. (Paris), 269 : 1870 (1969).

8) Folkers, K., Enzmann, F., B $\phi$ ler, J., Bowers, G.Y. and Schally, A.V.: Biochem. Biophys. Res. Comm. 37 : 123 (1969). $\quad$ 9) Bowers, G.Y., Schally, A.V., Schalch, D.S., Gual, G., Kastin, A.J., and Folkers, K. : Biochem. Biophys. Res. Comm, 39 : 352 (1970).

10) Fleischer, N., Burgus, R., Vale, W., Dunn, T. and Guillemin, R. : J. Glin. Endocri. 31 : 109 (1970). 11) Hershman, J.M., and Pittman, J.A. : J. Glin. Endocri. 31 : 457 (1970). 12) Hall, R., Amos, J., Garry, R. and Buxton, R.L. : Brit. Med. J. 2 : 274 (1970).

13）佐古田雅弘, 大槻 真, 日下孝明, 森顓太郎,

嶺山隆司：日内泌誌，46:826 (1970).

理夫：日内泌誌, $46: 821$ (1970).

nology, $88: 1503$ (1971).

Pittman, JR : Endocrinology, 87 : 1015 (1970).

and R.O. Studer : Helv. Chem. Acta. 53 : 63 (1970).
14）佐古田雅弘, 福田恒夫, 玉岡昌則, 深津泰良, 大久保

15) Kendell, J.W., L.H. Rees. and R. Kramer. : Endocri6) Baugh, G.M., G.J. Krumdieck, J.M. Hershman, and J.A. $63: 372$ (1958).

19) Saffran, M. and A.V. Scnally : Ganad. J. Biochem. Physio. 33 : 408 (1955). 20) Retiene, K., Zimmermann, Z., Schindler. W.J., Neuenschwander, J., and Lipscomb, H.S. : Acta Endocrinology, $57: 615$ (1968).

21）大槻 真，佐古田雅弘，弘重尚久，金尾啓介，

八木秋子, 本田 稔: ホルモンと臨床, $19: 473$ (1971). 22$)$ D.H. Andersen and H.S. Kennedy.: J. Physiol. $79: 1$ (1933). $\quad$ 23) D.H. Andersen. : Proc. Soc. Exp. Biol. Med. 30 : 657 (1933). 24) A.D. Litonjua. and B.V. Baylon, : Acta Medica Philippiana, Vol. 1. 204 (1965). 25) Hatani. S : J. Exp. Zool. : $18: 1$ (1915). $\quad$ 26) Sinha, D.K. and J. Meites, : Endocrinology, $78: 1002$ (1966). $\quad$ 27) Guillemin, R., and J. Meites. : In "Hypophysiotropic Hormones of the Hypothalamus": Assay and Chemistry Williams and WilkinsGo. Baltimore pp. 58 1970. 28) Tanaka, I. : Folia Endocrinologica Japonica, : $46: 230$ (1970). $\quad 29)$ Redding, T.W. and A.V. Schally : Endocrinology, $81: 918$ (1967). $\quad 30$ ) Bowers, G.Y., A.V. Schally, G. A. Reynolus. and W.D. Hawley : Endocrinology, 81 : 741 (1967). $\quad 31)$ G.Y. Bowers, A.V. Schally, F. Enzmann, J. Boler, and K. Folkers : Endocrinology, $86: 1143$ (1970). $\quad 32)$ Ito, S. : Federation Proceedings, $25: 1187$ (1966). $\quad 33$ ) Bowers, G.Y., A.V. Schally, W.D. Hawley, G. Gual, and A. Parlow : J. Glin. Endocri. $28: 978$ (1968). 34) 辻 昇三, 佐古田雅弘, 池村幸男 : 最新医学, $24: 628$ (1969).

35）大梘 真：日内泌誌，47，301（1971）。 36) Vale, W., R. Burgus, and R. Guillemin : Proc. Soc. Exp. Biol Med. 131 : 420 (1969).

37) Vale, W., R. Burgus, and R. Guillemin : Proc. Soc. Exp. Biol. Med. 125 : 210 (1967). 38) Snyder, P.J. and R.D. Utiger : J. Glin. Invest. $51: 2077$ (1972).

39) R.L.W. Averill. : Endocrinology, 85 : 67 (1969). 40) Vale, W., R. Bugus, and R. Guillemin : Neuroendocrinology,3 : 34 (1968).

41）辻 昇三, 佐古田雅

弘, 福田恒夫, 深津泰良 : 最新医学, $24: 1695$ (1969).

42）福田恒夫：日内泌誌, $46: 1169$ (1971).

43）森穎太郎：発表予定. 